\title{
Daily Intake of a Commercially Available Vegetable Juice Has Beneficial Effects on Metabolic Syndrome-Related Biomarkers in Young, Healthy Japanese Adults
}

\author{
Kazutaka Yoshida ${ }^{*}$, Mari Mori², Tatsuya Miyashita1, Shuko Murakami ${ }^{3}$, \\ Takahiro Inakuma ${ }^{4}$, Satoshi Sunabori1, Hiroyuki Suganuma1, Yukio Yamori' ${ }^{2,3}$ \\ ${ }^{1}$ Innovation Division, KAGOME Co. Ltd., Tochigi, Japan \\ ${ }^{2}$ Institution for World Health Development, Mukogawa Women's University, Hyogo, Japan \\ ${ }^{3}$ Hyogo Prefecture Health Promotion Association, Hyogo, Japan \\ ${ }^{4}$ Faculty of Contemporary Human Life Science, Department of Food and Nutrition, Tezukayama University, \\ Nara, Japan \\ Email: "Kazutaka_Yoshida@kagome.co.jp
}

Received 15 July 2016; accepted 21 August 2016; published 24 August 2016

Copyright (C) 2016 by authors and Scientific Research Publishing Inc.

This work is licensed under the Creative Commons Attribution International License (CC BY). http://creativecommons.org/licenses/by/4.0/

(c) (i) Open Access

\section{Abstract}

Adequate vegetable intake is important in reducing the risk of lifestyle-related diseases; however, intake amongst young Japanese adults is poor. This study aimed to assess the effect of daily intake of a commercially available vegetable juice on nutritional status and metabolic syndrome-related markers in healthy young adults. Fifty-one healthy adults (14 men, 37 women), age 20 - 22 years were recruited, and their food and nutritional intake was surveyed using an FFQ based on Food Groups. Subjects were divided into either a control group, who were not administered vegetable juice, or an intervention group, who consumed $200 \mathrm{~mL}$ vegetable juice daily for 2 months. Anthropometric data, serum carotenoid concentrations, blood and urinary parameters were measured at baseline and at 2 months. The average intake of vegetables in all subjects at baseline was approximately $140 \mathrm{~g} / \mathrm{day}$, less than half the dose recommended by the Japanese government. Total serum carotenoid concentration in the intervention group doubled from baseline after 2 months. In particular, serum concentrations of $\alpha$-carotene, $\beta$-carotene, and lycopene were increased. In the intervention group, 24-hour urinary potassium excretion increased significantly, and 24-hour urinary sodium to potassium ratio decreased significantly. Waist circumference and systolic blood pressure also decreased significantly. Daily intake of a commercial vegetable juice for 2 months improved nutritional status in young adults with inadequate vegetable intake, shown by improved

\footnotetext{
${ }^{*}$ Corresponding author.

How to cite this paper: Yoshida, K., Mori, M., Miyashita, T., Murakami, S., Inakuma, T., Sunabori, S., Suganuma, H. and Yamori, Y. (2016) Daily Intake of a Commercially Available Vegetable Juice Has Beneficial Effects on Metabolic SyndromeRelated Biomarkers in Young, Healthy Japanese Adults. Food and Nutrition Sciences, 7, 844-854.
}

http://dx.doi.org/10.4236/fns.2016.710084 
serum carotenoid and urine potassium levels. In addition, intake of vegetable juice may be beneficial in reducing the risk of metabolic syndrome.

\section{Keywords}

Vegetable Juice, Carotenoid, Potassium, Metabolic Syndrome, Urinary Sodium to Potassium Ratio

\section{Introduction}

Adequate intake of vegetables is very important in the prevention of lifestyle-related diseases [1]. In Japan, the National Health Promotion Campaigns for the 21st Century (Healthy Japan 21), advocated by the Ministry of Health, Labour, and Welfare, recommends that adults eat more than $350 \mathrm{~g}$ of vegetables per day for maintenance of good health [2] [3]. However, the average daily intake of vegetables for Japanese people is approximately 270 g. Intake is especially poor in young adults (between 20 and 29 years old), who eat approximately 230 g per day [4]. Intake of green-yellow vegetables rich in carotenoids is especially inadequate in this age group. Daily intake of carotenoid rich vegetables has been estimated at approximately $60 \mathrm{~g}$, only half of that recommended by Healthy Japan 21 [5]. Based on these observations, increasing vegetable intake in young Japanese adults is of urgent priority in the fields of nutrition and public health.

Carotenoids are important antioxidants abundant in vegetables. They are thought to prevent lifestyle-related diseases through their antioxidant properties and the function of vitamin A (retinol), derived from provitamin A carotenoids such as $\beta$-carotene and $\beta$-cryptoxanthin [6] [7]. Many epidemiological studies have revealed significant negative relationships between carotenoid intake or serum/plasma carotenoid levels and the risks of various lifestyle-related diseases [8]-[12].

Potassium is another important nutrient found in vegetables, and can also help to prevent lifestyle-related diseases. It contributes to the maintenance of normal blood pressure, and in the prevention of cardiovascular diseases [13] [14]. In particular, the balance of sodium and potassium intake is crucial for the prevention of hypertension. Urinary sodium to potassium ratio is thought to be a more useful biomarker in the evaluation of hypertension incidence than either sodium or potassium alone [15]. Intake of vegetables is known to be an effective means to improve urinary sodium to potassium ratio [16] [17].

Vegetable juice is thought to be a convenient alternative to the consumption of large amounts of vegetables, as it can still supply vital nutrients such as carotenoids and potassium. There are some reports that daily intake of vegetable juice increases dietary intake of such nutrients [18] [19], however the effects of vegetable juice on nutritional status and metabolic syndrome, a risk factor for lifestyle-related diseases such as cardiovascular disease, have not been extensively evaluated. In this study, we conducted an interventional study recruiting young Japanese adults, whose vegetable intake was thought to be inadequate. We investigated the effect of vegetable juice on serum carotenoid concentrations, urinary sodium to potassium ratio, and metabolic syndrome-related markers.

\section{Materials and Methods}

\subsection{Vegetable Juice}

A commercially available mixed vegetable juice named "Kagome Yasai-ichinichi-koreippon” (KAGOME Co. Ltd., Nagoya, Japan) was used as the experimental food. This juice consists of various vegetables (tomato, carrot, red bell pepper, Chinese cabbage, petit vert, kale, asparagus, watercress, parsley, pumpkin, celery, spinach, broccoli, onion, lettuce, cabbage, nalta jute, beetroot, white radish, komatsuna, ginger, purple sweet potato, Angelica keiskei [ashitaba], eggplant, and burdock). Nutritional information for the vegetable juice is shown in Table 1.

\subsection{Subjects}

The study protocols were approved by the Ethics Committee of Mukogawa Women's University and KAGOME CO., LTD., and were carried out in accordance with the International Ethical Guidelines and the Declaration of 
Table 1. Nutritional information of the vegetable juice used in this study.

\begin{tabular}{|c|c|}
\hline \multicolumn{2}{|c|}{ Nutritional information (per $200 \mathrm{~mL}$ ) } \\
\hline Energy $(\mathrm{kJ})^{\mathrm{a}}$ & 285 \\
\hline Protein $(g)^{\mathrm{a}}$ & 2.4 \\
\hline Fat $(g)^{a}$ & 0 \\
\hline Carbohydrate (g) & 13.4 \\
\hline Dietary fiber $(\mathrm{g})^{\mathrm{a}}$ & 2.3 \\
\hline Potassium (mg) ${ }^{\mathrm{a}}$ & 730 \\
\hline Folic acid $(\mu \mathrm{g})^{\mathrm{a}}$ & $13-110$ \\
\hline$\alpha$-Carotene (mg) ${ }^{\mathrm{b}}$ & 1.8 \\
\hline$\beta$-Carotene (mg) ${ }^{\mathrm{b}}$ & 5.3 \\
\hline Lycopene (mg) ${ }^{\mathrm{b}}$ & 11.9 \\
\hline
\end{tabular}

${ }^{\mathrm{a}}$ Values obtained from nutritional labeling of the commercial vegetable juice. ${ }^{\mathrm{b}}$ Values obtained using HPLC.

Helsinki. A total of 51 students from Hyogo University were recruited (14 men and 37 women), between 20 - 22 years of age. All subjects provided written informed consent to this study.

\subsection{Study Design}

Subjects were surveyed regarding their food and nutritional intake using an FFQ based on Food Groups (FFQg) and "Excel Eiyo-kun FFQg software" (version 2.0; Kenpakusha, Tokyo, Japan). The questionnaire was completed during the 6 days prior to the intervention period, and the energy and nutrient intake of each subject were estimated based on 29 food groups and 10 kinds of cooking [20]. Subsequently, subjects were divided in two groups: a control group $(\mathrm{N}=20 ; 6$ males and 14 females) and an intervention group $(\mathrm{N}=31 ; 8$ males and 23 females). The subjects in the intervention group consumed one pack of the vegetable juice daily $(200 \mathrm{~mL})$ for 2 months. No experimental food was applied to the control group throughout this study. Anthropometric data, blood, and urine samples were collected for all subjects at baseline and following the intervention period.

\subsection{Anthropometric Measurements and Collection of Blood and Urine Samples}

All subjects were asked to abstain from consuming any foods or drinks (other than water) after 9:00 pm on the day before anthropometric measurements and collection of blood and urine samples, until after the assessment. Height, body weight, and body fat ratio were measured with commonly available tools. Waist circumference was measured with a tape measure at the level of the navel. Systolic blood pressure (SBP) and diastolic blood pressure (DBP) were measured with an automated blood pressure measurement system (HEM-907; OMRON, Kyoto, Japan).

A blood sample was drawn from the antecubital vein for each patient, and the serum was used to determine serum carotenoid concentrations and blood parameters. A $24 \mathrm{~h}$ urine sample was collected using an aliquot cup [21] and was used to determine urine parameters.

\subsection{Measurement of Serum Carotenoid Concentrations}

Serum carotenoid levels (lutein, $\beta$-cryptoxanthin, $\alpha$-carotene, $\beta$-carotene, and lycopene) were determined by HPLC according to previous methods [22]-[25]. In brief, $200 \mu \mathrm{L}$ serum was prepared and $10 \mu \mathrm{L}$ ethanol containing trans- $\beta$-8'-apocarotenal $(10 \mu \mathrm{M})$ were added to the serum as an internal standard. Subsequently, $1 \mathrm{~mL}$ ethanol and a solution of n-hexane and dichloromethane $(4: 1, \mathrm{v} / \mathrm{v}, 4 \mathrm{~mL})$ were added, the mixture was centrifuged at $1087 \times \mathrm{g}$ for $10 \mathrm{~min}$, and the supernatant $(4 \mathrm{~mL})$ was evaporated under nitrogen gas. The residue was dissolved in $0.2 \mathrm{~mL}$ solvent mixture (n-hexane/acetone/ethanol/toluene, 10:7:6:7, v/v/v/v), and was filtered with a $0.2 \mu \mathrm{m}$ filter. HPLC analysis was performed using a C30 carotenoid column $(250 \times 4.6 \mathrm{~mm}, 5 \mu \mathrm{m}$; YMC, Wilmington, NC, USA) and a photodiode array detector (SPD-M10, Shimadzu, Kyoto, Japan) at a detecting wavelength of $460 \mathrm{~nm}$. Mobile phase A (A) consisted of a 75:15:10 mixture of methanol:tert-butyl-methyl- 
ether:water. Mobile phase B (B) consisted of an 8:90:2 mixture of methanol:tert-butyl-methyl-ether:water. Pumps were programmed to perform the following gradient at a flow rate of $1 \mathrm{~mL} / \mathrm{min}$ : start at $100 \% \mathrm{~A}$, a 25 min linear gradient to $100 \%$ B, 3 min at $100 \%$ B, a 2 min gradient back to $100 \%$ A, and 10 min at $100 \%$ A. Under these conditions, the concentrations of carotenoids were measured and corrected using an internal standard.

\subsection{Measurement of Blood and Urine Parameters}

Measurement of blood parameters (triglycerides [TG], HDL cholesterol [HDL-C], LDL cholesterol [LDL-C], total cholesterol [Total-C], blood glucose, HbA1c, insulin, high-sensitive C-reactive protein [Hs-CRP], folic acid, uric acid, red blood cell counts [RBCs], hemoglobin, and hematocrit) were outsourced to SRL (Tokyo, Japan). Homeostatic model assessment-Insulin Resistance (HOMA-IR) was calculated using the following formula [26];

$$
\text { HOMA }- \text { IR = Insulin level }(\mu \mathrm{U} / \mathrm{mL}) \times \text { Blood glucose level }(\mathrm{mg} / \mathrm{dL}) \div 405 .
$$

Blood homocysteine was measured by Alfresa Pharma Corporation (Osaka, Japan). Urine samples were analyzed by the Mukogawa Women’s University Institute for World Health Development [27].

\subsection{Statistical Analysis}

All values are represented as mean \pm standard deviation. Paired $t$-tests were used for comparisons within each group before and after the intervention. Data were analyzed using SPSS for Windows version 15.0 (SPSS Japan Inc, Tokyo, Japan). Values of $p<0.05$ were accepted as significant.

\section{Results}

\subsection{Subjects}

Of the 51 recruited participants, 38 completed the study (15/20 in the control group, 23/31 in the intervention group). Of the participants who failed to complete the study, 2 subjects ( 1 control, 1 intervention) were lost to follow-up after the intervention period, 10 (4 control, 6, intervention) did not complete urine sampling, and 1 subject in the intervention group was omitted from data analysis due to poor compliance in drinking vegetable juice (Figure 1).

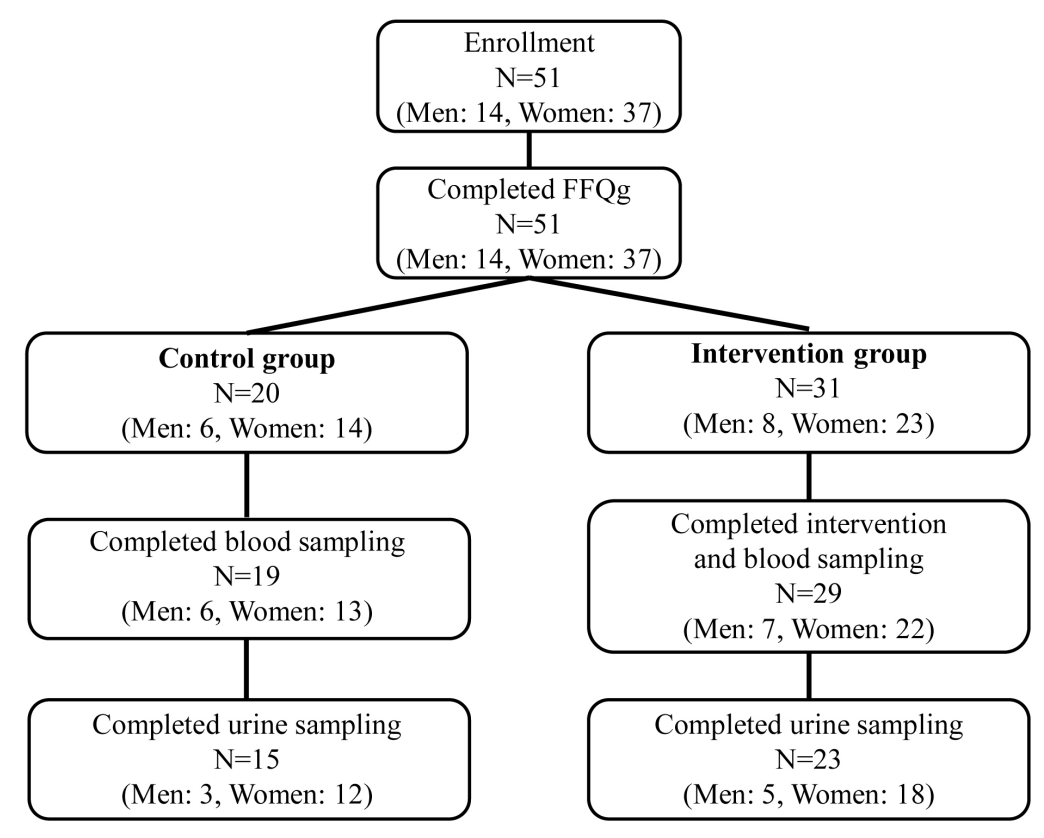

Figure 1. A flow diagram of participant recruitment is shown, including enrollment, grouping by control or intervention, and reasons for incomplete data. 


\subsection{Food and Nutritional Intake}

The average daily intake of vegetables and green-yellow vegetables in all subjects were approximately $140 \mathrm{~g}$ and $50 \mathrm{~g}$, respectively (Table 2). The average intakes of major nutrients (vitamins, minerals, and dietary fiber) were calculated using the FFQg and are also described in Table 2.

\subsection{Serum Carotenoid Concentrations}

Total carotenoid concentrations after the intervention period in the intervention group were more than twice the initial concentration $(1.36 \pm 0.81 \mu \mathrm{M}$ vs $3.56 \pm 1.29 \mu \mathrm{M} ; p<0.001)$. Among the carotenoids assessed, concentrations of $\alpha$-carotene, $\beta$-carotene, and lycopene were significantly increased after the intervention period ( 0.17 $\mu \mathrm{M}$ vs $0.77 \mu \mathrm{M} ; p<0.001,0.45 \mu \mathrm{M}$ vs $1.71 \mu \mathrm{M} ; p<0.001,0.22 \mu \mathrm{M}$ vs $0.60 \mu \mathrm{M} ; p<0.001$, respectively) (Table 3).

Table 2. Vegetable and nutrient intake is shown for study participants at baseline.

\begin{tabular}{|c|c|c|c|}
\hline & Men $(n=14)$ & Women $(n=37)$ & Total $(\mathrm{n}=51)$ \\
\hline & Mean \pm SD & Mean \pm SD & Mean \pm SD \\
\hline \multicolumn{4}{|l|}{ Vegetables } \\
\hline Total vegetables (g) & $135 \pm 72$ & $141 \pm 63$ & $139 \pm 65$ \\
\hline Green-yellow vegetables (g) & $49 \pm 34$ & $49 \pm 27$ & $49 \pm 29$ \\
\hline Other vegetables (g) & $85 \pm 45$ & $92 \pm 46$ & $90 \pm 45$ \\
\hline \multicolumn{4}{|l|}{ Vitamins } \\
\hline Vitamin A ( $\mu$ g RAE) & $469 \pm 151$ & $440 \pm 165$ & $448 \pm 161$ \\
\hline Folic acid $(\mu \mathrm{g})$ & $217 \pm 81$ & $190 \pm 49$ & $197 \pm 60$ \\
\hline Vitamin E (mg) & $11.3 \pm 1.6$ & $10.7 \pm 1.2$ & $10.9 \pm 1.3$ \\
\hline Vitamin K ( $\mu \mathrm{g})$ & $165 \pm 74$ & $138 \pm 42$ & $145 \pm 53$ \\
\hline \multicolumn{4}{|l|}{ Minerals } \\
\hline Potassium (mg) & $2170 \pm 591$ & $1759 \pm 440$ & $1872 \pm 514$ \\
\hline Calcium (mg) & $516 \pm 191$ & $455 \pm 192$ & $472 \pm 192$ \\
\hline Magnesium (mg) & $236 \pm 73$ & $178 \pm 43$ & $194 \pm 59$ \\
\hline Iron (mg) & $7.1 \pm 2.1$ & $6.0 \pm 2.9$ & $6.3 \pm 2.7$ \\
\hline \multicolumn{4}{|l|}{ Other } \\
\hline Dietary fiber (g) & $10.4 \pm 4.1$ & $9.0 \pm 2.3$ & $9.4 \pm 2.9$ \\
\hline
\end{tabular}

Data is show as mean \pm standard deviation (SD). RAE: retinol activity equivalents.

Table 3. Serum carotenoid concentrations are shown at baseline and after the interventional period.

\begin{tabular}{|c|c|c|c|c|c|c|}
\hline & \multicolumn{3}{|c|}{ Control group $(\mathrm{n}=19)$} & \multicolumn{2}{|c|}{ Intervention group $(n=29)$} & \multirow{3}{*}{$p$ value } \\
\hline & Baseline & After 2 months & \multirow{2}{*}{$P$ value } & Baseline & After 2 months & \\
\hline & Mean \pm SD & Mean \pm SD & & Mean \pm SD & Mean \pm SD & \\
\hline Lutein $(\mu \mathrm{M})$ & $0.29 \pm 0.1$ & $0.21 \pm 0.09$ & $0.004^{* *}$ & $0.33 \pm 0.12$ & $0.25 \pm 0.09$ & $<0.001^{* * *}$ \\
\hline$\beta$-Cryptoxanthin $(\mu \mathrm{M})$ & $0.15 \pm 0.08$ & $0.18 \pm 0.13$ & 0.244 & $0.19 \pm 0.1$ & $0.22 \pm 0.09$ & $0.012^{*}$ \\
\hline$\alpha$-Carotene $(\mu \mathrm{M})$ & $0.11 \pm 0.09$ & $0.20 \pm 0.15$ & $0.009^{* *}$ & $0.17 \pm 0.17$ & $0.77 \pm 0.30$ & $<0.001^{* * *}$ \\
\hline$\beta$-Carotene $(\mu \mathrm{M})$ & $0.32 \pm 0.28$ & $0.41 \pm 0.39$ & 0.084 & $0.45 \pm 0.43$ & $1.71 \pm 0.81$ & $<0.001^{* * *}$ \\
\hline Lycopene $(\mu \mathrm{M})$ & $0.23 \pm 0.11$ & $0.32 \pm 0.23$ & $0.028^{*}$ & $0.22 \pm 0.12$ & $0.60 \pm 0.17$ & $<0.001^{* * *}$ \\
\hline Total carotenoid $(\mu \mathrm{M})$ & $1.10 \pm 0.56$ & $1.32 \pm 0.82$ & 0.134 & $1.36 \pm 0.81$ & $3.56 \pm 1.29$ & $<0.001^{* * *}$ \\
\hline
\end{tabular}

Data is shown as mean \pm standard deviation (SD). Baseline vs. After 2 months, paired $t$-tests, ${ }^{*} p<0.05,{ }^{* *} p<0.01,{ }^{* * *} p<0.001$. 


\subsection{Anthropometric Data}

No significant changes were observed when participants in the control group were compared before and after the intervention period. In contrast, continual intake of the vegetable juice for 2 months significantly decreased waist circumference and SBP ( $p=0.006$ and $p=0.034$, respectively) (Table 4).

\subsection{Blood Parameters}

The blood parameters in the both groups at baseline and after the intervention period are shown in Table 5. Among the parameters related to lipid metabolism, LDL-C and Total-C levels were significantly increased in the

Table 4. Anthropometric data are shown at baseline and after the interventional period.

\begin{tabular}{|c|c|c|c|c|c|c|}
\hline & \multicolumn{2}{|c|}{ Control group $(n=19)$} & \multirow{3}{*}{$p$ value } & \multicolumn{2}{|c|}{ Intervention group $(n=29)$} & \multirow{3}{*}{$p$ value } \\
\hline & Baseline & After 2 months & & Baseline & After 2 months & \\
\hline & Mean \pm SD & Mean \pm SD & & Mean \pm SD & Mean \pm SD & \\
\hline Weight (kg) & $59.9 \pm 14.7$ & $59.9 \pm 15.8$ & 0.913 & $57.0 \pm 12.3$ & $56.9 \pm 12.9$ & 0.542 \\
\hline Body fat ratio (\%) & $24.9 \pm 5.6$ & $25.0 \pm 4.8$ & 0.691 & $23.9 \pm 6.6$ & $24.3 \pm 6.3$ & 0.216 \\
\hline $\operatorname{BMI}\left(\mathrm{kg} / \mathrm{m}^{2}\right)$ & $21.8 \pm 4.1$ & $21.7 \pm 4.4$ & 0.874 & $21.6 \pm 4.0$ & $21.5 \pm 4.2$ & 0.247 \\
\hline $\begin{array}{l}\text { Waist circumference } \\
(\mathrm{cm})\end{array}$ & $75.4 \pm 12.5$ & $75.1 \pm 12.1$ & 0.795 & $75.3 \pm 10.0$ & $74.2 \pm 10.2$ & $0.006^{* *}$ \\
\hline SBP (mmHg) & $117.6 \pm 14.5$ & $113.7 \pm 14.4$ & 0.170 & $114.3 \pm 13.1$ & $109.0 \pm 11.8$ & $0.034^{*}$ \\
\hline DBP (mmHg) & $68.6 \pm 7.1$ & $68.1 \pm 7.7$ & 0.566 & $67.0 \pm 8.2$ & $68.3 \pm 7.8$ & 0.473 \\
\hline
\end{tabular}

Data is shown as mean \pm standard deviation (SD). Baseline vs. After 2 months, paired $t$-tests, ${ }^{*} p<0.05,{ }^{* *} p<0.01$. BMI: body mass index; SBP: systolic blood pressure; DBP: diastolic blood pressure.

Table 5. Blood parameters are shown at baseline and after the interventional period.

\begin{tabular}{|c|c|c|c|c|c|c|}
\hline & \multicolumn{2}{|c|}{ Control group $(n=19)$} & \multirow{3}{*}{$p$ value } & \multicolumn{2}{|c|}{ Intervention group $(\mathrm{n}=29)$} & \multirow{3}{*}{$p$ value } \\
\hline & Baseline & After 2 months & & Baseline & After 2 months & \\
\hline & Mean \pm SD & Mean \pm SD & & Mean \pm SD & Mean \pm SD & \\
\hline $\mathrm{TG}(\mathrm{mg} / \mathrm{dL})$ & $69.7 \pm 29.2$ & $78.6 \pm 42.0$ & 0.445 & $73.5 \pm 42.9$ & $76.9 \pm 48.5$ & 0.660 \\
\hline HDL-C (mg/dL) & $59.6 \pm 12.1$ & $58.2 \pm 10.5$ & 0.242 & $58.4 \pm 12.6$ & $59.5 \pm 11.5$ & 0.432 \\
\hline LDL-C (mg/dL) & $91.5 \pm 22.1$ & $101.8 \pm 23.6$ & $<0.001^{* * *}$ & $90.4 \pm 28.8$ & $100.2 \pm 27.3$ & $<0.001^{* * *}$ \\
\hline Total-C (mg/dL) & $165.3 \pm 25.3$ & $176.3 \pm 23.3$ & $0.007^{* *}$ & $164.7 \pm 33.7$ & $177.1 \pm 25.9$ & $<0.001^{* * *}$ \\
\hline Glucose (mg/dL) & $89.0 \pm 6.4$ & $87.3 \pm 6.3$ & 0.175 & $89.6 \pm 4.0$ & $87.6 \pm 4.2$ & $0.019^{*}$ \\
\hline HbA1c (\%) & $4.7 \pm 0.2$ & $4.8 \pm 0.2$ & $0.005^{* *}$ & $4.7 \pm 0.2$ & $4.8 \pm 0.2$ & 0.660 \\
\hline Insulin $(\mu \mathrm{IU} / \mathrm{mL})$ & $9.2 \pm 4.5$ & $9.5 \pm 4.0$ & 0.820 & $8.1 \pm 4.3$ & $7.8 \pm 4.0$ & 0.589 \\
\hline HOMA-IR & $2.1 \pm 1.1$ & $2.1 \pm 1.0$ & 0.992 & $1.9 \pm 1.2$ & $1.8 \pm 1.1$ & 0.376 \\
\hline $\begin{array}{l}\text { Homocysteine } \\
(\mu \mathrm{mol} / \mathrm{L})\end{array}$ & $11.8 \pm 6.8$ & $13.0 \pm 8.2$ & $0.015^{*}$ & $11.9 \pm 8.9$ & $11.7 \pm 6.6$ & 0.619 \\
\hline Folic acid (ng/mL) & $5.1 \pm 1.5$ & $6.3 \pm 2.2$ & $0.010^{*}$ & $5.1 \pm 1.6$ & $6.9 \pm 2.1$ & $<0.001^{* * *}$ \\
\hline Uric acid (mg/dL) & $5.1 \pm 1.4$ & $5.0 \pm 1.3$ & 0.678 & $5.1 \pm 1.2$ & $5.1 \pm 1.2$ & 0.518 \\
\hline Hs-CRP (mg/dL) & $0.7 \pm 1.4$ & $0.2 \pm 0.3$ & 0.129 & $0.5 \pm 1.0$ & $0.3 \pm 0.4$ & 0.301 \\
\hline RBCs $\left(10^{4}\right.$ cells $\left./ \mu \mathrm{L}\right)$ & $469.3 \pm 41.8$ & $468.8 \pm 40.9$ & 0.949 & $458.1 \pm 43.1$ & $466.6 \pm 43.2$ & 0.059 \\
\hline Hemoglobin (g/dL) & $14.0 \pm 1.8$ & $14.2 \pm 1.4$ & 0.298 & $13.5 \pm 1.7$ & $14.1 \pm 1.4$ & $0.006^{* *}$ \\
\hline Hematocrit (\%) & $42.4 \pm 5.1$ & $42.3 \pm 4.0$ & 0.821 & $41.0 \pm 4.6$ & $42.2 \pm 3.6$ & $0.037^{*}$ \\
\hline
\end{tabular}

Data is shown as mean \pm standard deviation (SD). Baseline vs. After 2 months, paired $t$-tests, ${ }^{*} p<0.05,{ }^{* *} p<0.01,{ }^{* * *} p<0.001$. TG: triglyceride; HDL-C: HDL cholesterol; LDL-C: LDL cholesterol; Total-C: total cholesterol; HOMA-IR: Homeostatic model assessment-Insulin Resistance; Hs-CRP: high-sensitive C-reactive protein; RBCs: red blood cell counts. 
intervention group after 2 months, however these changes were also observed in the control group. Among the parameters related to glucose metabolism, fasting blood glucose was significantly decreased in the intervention group $(p=0.019)$ and HbA1c level was significantly increased in the control group $(p=0.015)$. Folic acid level was significantly increased in both the control and intervention groups ( $p=0.010$ and $p<0.001$, respectively). Homocysteine level was significantly increased in the control group $(p=0.010)$. Hemoglobin and hematocrit levels were significantly increased in the intervention group ( $p=0.006$ and $p=0.037$, respectively).

\subsection{Urine Parameters}

The daily sodium excretion amount was not significantly different before and after the intervention period in the both groups. In contrast, daily urinary potassium excretion was significantly increased, and the urinary sodium to potassium ratio was significantly decreased in the intervention group after the intervention period $(p<0.001$ and $p<0.001$, respectively) (Table 6).

\section{Discussion}

Our study strongly confirmed that young Japanese adults consume inadequate amounts of vegetables relative to current public recommendations [2] [4] [5]. The average vegetable intake of all subjects was approximately 140 g/day and this was surprisingly only $40 \%$ of the amount recommended ( $350 \mathrm{~g} /$ day) by the Japanese government [2]. Moreover, intake of green-yellow vegetables in the subjects ( $50 \mathrm{~g} / \mathrm{day}$ ) was also about $40 \%$ of the recommendation amount (120 g/day) [2]. This result is consistent with a previous report demonstrating that the average intake of green-yellow vegetables in young unmarried subjects was only 50\% of the recommended level [5].

The "Dietary Reference Intakes (DRIs) for Japanese” proposes reference values for desirable dietary energy and nutrient intake by Japanese people to maintain and promote their health [28]. Compared with the "DRIs for Japanese" [28], the intake of vitamin A, vitamin C, calcium, magnesium, and dietary fiber in our study subjects were less than $70 \%$ of the recommended amounts. These deficiencies likely reflect inadequate vegetable intake in the subjects. Potassium intake was more than $80 \%$ of the amount recommended in Japan $(2500 \mathrm{mg} /$ day for men, $2000 \mathrm{mg} /$ day for women). However, this was not adequate compared to the recommendation by the WHO (at least $90 \mathrm{mmol} / \mathrm{day}$ (3510 mg/day) for adults) to reduce blood pressure and to decrease risk of cardiovascular diseases [29].

The total average serum carotenoid in the subjects before the intervention period was less than $1.5 \mu \mathrm{M}$ and was remarkably lower than the levels recently reported in Japan [30]-[34]. The daily intake of vegetable juice significantly increased total serum carotenoid concentration to approximately $3.5 \mu \mathrm{M}$, more than twice that of the baseline level. In particular, serum concentrations of $\alpha$-carotene, $\beta$-carotene, and lycopene were increased. These increases were most likely due to the interventional vegetable juice, which was high in carotenoids. Donaldson established a carotenoid health index by analyzing 62 studies of plasma carotenoids and health outcomes, and proposed risk categories as follows: "very high risk": $<1.0 \mu \mathrm{M}$, "high risk": $1.0-1.5 \mu \mathrm{M}$, "moderate risk": $1.5-2.5 \mu \mathrm{M}$, "low risk": $2.5-4.0 \mu \mathrm{M}$, and "very low risk": $>4.0 \mu \mathrm{M}$ [9]. In this study, of the 29 subjects whom completed vegetable juice supplementation and blood sampling, 23 (79\%) were categorized in "very high risk" or "high risk" group at baseline, however only 2 (7\%) remained in this group following the intervention period. Similarly, only 2 (7\%) were categorized as “low risk" or "very low risk" before the intervention, and this increased to 25 (86\%) following intervention. These results suggest that daily consumption of a commercially

Table 6. Urine parameters are shown at baseline and after the interventional period.

\begin{tabular}{|c|c|c|c|c|c|c|}
\hline & \multicolumn{2}{|c|}{ Control group $(\mathrm{n}=15)$} & \multirow{3}{*}{$p$ value } & \multicolumn{2}{|c|}{ Intervention group $(\mathrm{n}=23)$} & \multirow{3}{*}{$p$ value } \\
\hline & Baseline & After 2 months & & Baseline & After 2 months & \\
\hline & Mean \pm SD & Mean \pm SD & & Mean \pm SD & Mean \pm SD & \\
\hline Sodium (g/day) & $3.9 \pm 1.8$ & $3.8 \pm 2.2$ & 0.874 & $3.7 \pm 1.5$ & $3.7 \pm 1.0$ & 0.887 \\
\hline Potassium (g/day) & $1.3 \pm 0.4$ & $1.4 \pm 0.6$ & 0.667 & $1.3 \pm 0.3$ & $1.9 \pm 0.5$ & $<0.001^{* * * *}$ \\
\hline $\begin{array}{l}\text { Sodium to potassium } \\
\text { ratio }(\mathrm{mEq} / \mathrm{L} / \mathrm{mEq} / \mathrm{L})\end{array}$ & $5.1 \pm 2.1$ & $4.6 \pm 1.6$ & 0.488 & $4.9 \pm 1.6$ & $3.5 \pm 1.0$ & $<0.001^{* * *}$ \\
\hline
\end{tabular}

Data is shown as mean \pm standard deviation (SD). Baseline vs. After 2 months, paired $t$-tests, ${ }^{* * * *} p<0.001$. 
available vegetable juice may be sufficient to maintain an adequate serum carotenoid level.

Previously, the cross-sectional INTERMAP study surveyed nutrient intake among individuals from China, Japan, the UK, and US, and assessed possible relationships between dietary patterns and risk of circulatory diseases. 36 The study showed that individuals from Japan and China had a higher urinary sodium to potassium ratio than that of Western people, and it was postulated that this was likely to have adverse effects on blood pressure and higher mortality due to stroke. The average baseline urinary sodium to potassium ratio in this study (Men; 5.2, Women; 4.9) was marginally higher than that of Japanese adults in the INTERMAP study (Men; 4.5, Women; 4.1) [35]. In the intervention group, urinary potassium excretion was significantly increased and urinary sodium to potassium ratio was significantly decreased after the intervention period. Moreover, SBP levels were significantly decreased in the intervention group, corresponding to the reduction in urinary sodium to potassium ratio. The vegetable juice used in this study contained $730 \mathrm{mg}$ of potassium per $200 \mathrm{~mL}$, and daily intake was therefore likely to increase urinary potassium concentration, improve sodium to potassium ratio, and reduce SBP in the intervention group. The presence of other anti-hypertensive compounds may also have contributed to these findings. Tomato, the most common raw material in the vegetable juice, contains significant quantities of $\gamma$-aminobutyric acid (GABA) [36], which has been shown to exhibit anti-hypertensive effects in human intervention studies [37]-[39]. This may also provide a mechanism contributing to decreased SBP resulting from juice supplementation.

Previous studies have shown that lycopene and its metabolites can modulate lipid metabolism [40]-[42]. Moreover, a recent human interventional study showed that tomato juice supplementation reduced waist circumference and serum levels of cholesterol and inflammatory adipokines associated with increased serum lycopene levels [43]. We also observed a significant reduction in waist circumference and a concomitant increase in serum lycopene in the intervention group. The lycopene dose in this study (approximately $12 \mathrm{mg}$ ) was less than half of that in the previous interventional study (more than $30 \mathrm{mg}$ ). However, the significant increase in serum lycopene may have contributed to the reduction in waist circumference. Larger scale interventional studies are required to confirm the effect of lycopene on waist circumference and to clarify the underlying mechanism.

Daily supplementation with vegetable juice significantly decreased fasting blood glucose, and the increase in HbA1c observed in the control group was suppressed in the intervention group. Vegetables contain large amounts of dietary fiber, which is known to attenuate postprandial blood glucose elevation [44] [45]. Recently, we revealed that consumption of a commercially available vegetable juice prior to, or concomitantly with a meal also exerted similar effects on postprandial blood glucose [46]. Postprandial glycemic control during the day is important to control fasting glycemia and to prevent insulin resistance [47]. The daily consumption of vegetable juice may be beneficial in the prevention of diabetes by facilitating glycemic control.

Homocysteine, a derivative of methionine, has been confirmed as a risk factor for ischemic heart disease and other vascular disorders [48]. In contrast, folic acid is known to reduce homocysteine levels by promoting the conversion from homocysteine to methionine [49] [50]. The experimental vegetable juice contained folic acid, although the content was variable (nutritional label: 13 to $110 \mu \mathrm{g} / 200 \mathrm{~mL}$ ), and an increase of serum folic acid was observed, particularly in the intervention group. This may explain why an increase in serum homocysteine levels was observed only in the control group.

Interestingly, vegetable juice supplementation increased hemoglobin and hematocrit levels, which are indicators of anemia. A human interventional study showed that vitamin A improved nonheme iron absorption from rice, wheat and corn, and the effect was also exerted by $\beta$-carotene, a major provitamin A carotenoid [51]. Provitamin A carotenoid-rich vegetables were also shown to increase hemoglobin levels and decrease anemia rate with no effect on iron deficiency [52]. Daily intake of vegetable juice might therefore be expected to be beneficial on the reduction of anemia although the relevant mechanisms have not been established.

\section{Conclusion}

We conducted an interventional study assessing the effects of a commercially available vegetable juice on the nutritional status of young Japanese adults, whose vegetable intake was thought to be inadequate. Daily intake of the vegetable juice for 2 months beneficially modulated markers of metabolic syndrome such as waist circumference, urinary sodium to potassium ratio, and serum homocysteine. Concomitant increases in serum carotenoids, urine potassium, and serum folic acid were observed. These results suggest that vegetable juice consumption elicits multiple benefits in the prevention of metabolic syndrome and lifestyle related diseases. 


\section{References}

[1] Hooper, L. (2001)Dietetic Guidelines: Diet in Secondary Prevention of Cardiovascular Disease. Journal of Human Nutrition and Dietetics, 14, 297-305. http://dx.doi.org/10.1046/j.1365-277x.2001.00298.x

[2] The Ministry of Health, Labour and Welfare (2012) Health Japan 21 (The Second Term). http://www.mhlw.go.jp/file/06-Seisakujouhou-10900000-Kenkoukyoku/0000047330.pdf

[3] Ishikawa, M., Kusama, K. and Shikanai, S. (2015) Food and Nutritional Improvement Action of Communities in Japan: Lessons for the World. Journal of Nutritional Science and Vitaminology (Tokyo), 61, S55-S57. http://dx.doi.org/10.3177/jnsv.61.S55

[4] Ministry of Health, Labour and Welfare (2013) The National Health and Nutrition Survey Japan. (In Japanese) http://www.mhlw.go.jp/bunya/kenkou/eiyou/dl/h25-houkoku-04.pdf

[5] Hosotani, K. and Kitagawa, M. (2007) Measurement of Individual Differences in Intake of Green and Yellow Vegetables and Carotenoids in Young Unmarried Subjects. Journal of Nutritional Science and Vitaminology (Tokyo), 53, $207-$ 212. http://dx.doi.org/10.3177/jnsv.53.207

[6] Tapiero, H., Townsend, D.M. and Tew, K.D. (2004) The Role of Carotenoids in the Prevention of Human Pathologies. Biomed Pharmacother, 58, 100-110. http://dx.doi.org/10.1016/j.biopha.2003.12.006

[7] Rao, A.V. and Rao, L.G. (2007) Carotenoids and Human Health. Pharmacological Research, 55, 207-216. http://dx.doi.org/10.1016/j.phrs.2007.01.012

[8] Sluijs, I., Beulens, J.W., Grobbee, D.E. and van der Schouw, Y.T. (2009) Dietary Carotenoid Intake Is Associated with Lower Prevalence of Metabolic Syndrome in Middle-Aged And Elderly Men. Journal of Nutrition, 139, 987-992. http://dx.doi.org/10.3945/jn.108.101451

[9] Donaldson, M.S. (2011) A Carotenoid Health Index Based on Plasma Carotenoids and Health Outcomes. Nutrients, 3, 1003-1022. http://dx.doi.org/10.3390/nu3121003

[10] Beydoun, M.A., Shroff, M.R., Chen, X., Beydoun, H.A., Wang, Y. and Zonderman, A.B. (2011) Serum Antioxidant Status Is Associated with Metabolic Syndrome among US Adults in Recent National Surveys. Journal of Nutrition, 141, 903-913. http://dx.doi.org/10.3945/jn.110.136580

[11] Beydoun, M.A., Canas, J.A., Beydoun, H.A., Chen, X., Shroff, M.R. and Zonderman, A.B. (2012) Serum Antioxidant Concentrations and Metabolic Syndrome Are Associated among US Adolescents in Recent National Surveys. Journal of Nutrition, 142, 1693-1704. http://dx.doi.org/10.3945/jn.112.160416

[12] Li, Y., Guo, H., Wu, M. and Liu, M. (2013) Serum and Dietary Antioxidant Status Is Associated with Lower Prevalence of the Metabolic Syndrome in a Study in Shanghai, China. Asia Pacific Journal of Clinical Nutrition, 22, 60-68.

[13] Whelton, P.K., He, J., Cutler, J.A., Brancati, F.L., Appel, L.J., Follmann, D. and Klag, M.J. (1997) Effects of Oral Potassium on Blood Pressure. Meta-Analysis of Randomized Controlled Clinical Trials. Journal of the American Medical Association, 277, 1624-1632. http://dx.doi.org/10.1001/jama.1997.03540440058033

[14] Sacks, F.M., Willett, W.C., Smith, A., Brown, L.E., Rosner, B. and Moore, T.J. (1998) Effect on Blood Pressure of Potassium, Calcium, and Magnesium in Women with Low Habitual Intake. Hypertension, 31, 131-138. http://dx.doi.org/10.1161/01.HYP.31.1.131

[15] Perez, V. and Chang, E.T. (2014) Sodium to Potassium Ratio and Blood Pressure, Hypertension, and Related Factors. Advances in Nutrition, 5, 712-741. http://dx.doi.org/10.3945/an.114.006783

[16] Tuekpe, M.K., Todoriki, H., Sasaki, S., Zheng, K.C. and Ariizumi, M. (2006) Potassium Excretion in Healthy Japanese Women Was Increased by a Dietary Intervention Utilizing Home-Parcel Delivery of Okinawan Vegetables. Hypertension Research, 29, 389-396. http://dx.doi.org/10.1291/hypres.29.389

[17] Mori, M., Hamada, A., Mori, H., Yamori, Y. and Tsuda, K. (2012) Effects of Cooking Using Multiply Cookware on Absorption of Potassium and Vitamins: A Randomized Double-Blind Placebo Control Study. International Journal of Food Sciences and Nutrition, 63, 530-536. http://dx.doi.org/10.3109/09637486.2011.642342

[18] Shenoy, S.F., Kazaks, A.G., Holt, R.R., Chen, H.J., Winters, B.L., Khoo, C.S., Poston, W.S., Haddock, C.K., Reeves, R.S., Foreyt, J.P., Gershwin, M.E. and Keen, C.L. (2010) The Use of a Commercial Vegetable Juice as a Practical Means to Increase Vegetable Intake: A Randomized Controlled Trial. Nutrition Journal, 9, 38. http://dx.doi.org/10.1186/1475-2891-9-38

[19] Aiso, I., Inoue, H., Seiyama, Y. and Kuwano, T. (2014) Compared with the Intake of Commercial Vegetable Juice, the Intake of Fresh Fruit and Komatsuna (Brassica rapa L. var. perviridis) Juice Mixture Reduces Serum Cholesterol in Middle-Aged Men: A Randomized Controlled Pilot Study. Lipids in Health and Disease, 13, 102. http://dx.doi.org/10.1186/1476-511X-13-102

[20] Takahashi, K., Yoshimura, Y., Kaimoto, T., Kunii, D., Komatsu, T. and Yamamoto, S. (2001) Validation of a Food Frequency Questionnaire Based on Food Groups for Estimating Individual Nutrient Intake. The Japanese Journal of 
Nutrition and Dietetics, 59, 221-232. http://dx.doi.org/10.5264/eiyogakuzashi.59.221

[21] Yamori, Y., Nara, Y., Kihara, M., Mano, M. and Horie, R. (1984) Simple Method for Sampling Consecutive 24-Hour Urine for Epidemiological and Clinical Studies. Clinical and Experimental Hypertension. Part A: Theory and Practice, 6, 1161-1167. http://dx.doi.org/10.3109/10641968409039588

[22] Oshima, S., Sakamoto, H., Ishiguro, Y. and Terao, J. (1997) Accumulation and Clearance of Capsanthin in Blood Plasma after the Ingestion of Paprika Juice in Men. The Journal of Nutrition, 127, 1475-1479.

[23] Aizawa, K. and Inakuma, T. (2007) Quantitation of Carotenoids in Commonly Consumed Vegetables in Japan. Food Science and Technology Research, 13, 247-252. http://dx.doi.org/10.3136/fstr.13.247

[24] Yoshida, K., Yokoyama, H., Oteki, T., Matsumoto, G., Aizawa, K. and Inakuma, T. (2011) Evaluation of the Effect of Dietary Lycopene, the Main Carotenoid in Tomato (Lycopersicon esculentum), on the in Vivo Renal Reducing Ability by a Radiofrequency Electron Paramagnetic Resonance Method. Journal of Agricultural and Food Chemistry, 59, 2966-2971. http://dx.doi.org/10.1021/jf1041883

[25] Kodama, Y., Kishimoto, Y., Muramatsu, Y., Tatebe, J., Yamamoto, Y., Hirota, N., Itoigawa, Y., Atsuta, R., Koike, K., Sato, T., Aizawa, K., Takahashi, K., Morita, T., Homma, S., Seyama, K. and Ishigami, A. (2016) Antioxidant Nutrients in Plasma of Japanese Patients with Chronic Obstructive Pulmonary Disease (COPD), Asthma-COPD Overlap Syndrome, and Bronchial Asthma. The Clinical Respiratory Journal. [Epub Ahead of Print] http://dx.doi.org/10.1111/crj.12436

[26] Matthews, D.R., Hosker, J.P., Rudenski, A.S., Naylor, B.A., Treacher, D.F. and Turner, R.C. (1985) Homeostasis Model Assessment: Insulin Resistance and Beta-Cell Function from Fasting Plasma Glucose and Insulin Concentrations in Man. Diabetologia, 28, 412-419. http://dx.doi.org/10.1007/BF00280883

[27] Yamori, Y., Liu, L., Mizushima, S., Ikeda, K. and Nara, Y., CARDIAC Study Group (2006) Male Cardiovascular Mortality and Dietary Markers in 25 Population Samples of 16 Countries. Journal of Hypertension, 24, 1499-1505. http://dx.doi.org/10.1097/01.hjh.0000239284.12691.2e

[28] The Ministry of Health, Labor and Welfare (2015) Overview of Dietary Reference Intakes for Japanese. http://www.mhlw.go.jp/file/06-Seisakujouhou-10900000-Kenkoukyoku/Overview.pdf

[29] WHO (2012) Guideline: Potassium Intake for Adults and Children, Geneva, World Health Organization (WHO). http://www.who.int/nutrition/publications/guidelines/potassium_intake_printversion.pdf

[30] Sugiura, M., Nakamura, M., Ogawa, K., Ikoma, Y. and Yano, M. (2012) High Serum Carotenoids Associated with Lower Risk for Bone Loss and Osteoporosis in Post-Menopausal Japanese Female Subjects: Prospective Cohort Study. PLoS ONE, 7, e52643. http://dx.doi.org/10.1371/journal.pone.0052643

[31] Suzuki, K., Honjo, H., Ichino, N., Osakabe, K., Sugimoto, K., Yamada, H., Kusuhara, Y., Watarai, R., Hamajima, T., Hamajima, N. and Inoue, T. (2013) Association of Serum Carotenoid Levels with Urinary Albumin Excretion in a General Japanese Population: The Yakumo Study. Journal of Epidemiology, 23, 451-456. http://dx.doi.org/10.2188/jea.JE20130058

[32] Suzuki, K., Ishii, J., Kitagawa, F., Kuno, A., Kusuhara, Y., Ochiai, J., Ichino, N., Osakabe, K., Sugimoto, K., Yamada, H., Ito, Y., Hamajima, N. and Inoue, T. (2013) Association of Serum Carotenoid Levels with N-Terminal Pro-BrainType Natriuretic Peptide: A Cross-Sectional Study In Japan. Journal of Epidemiology, 23, 163-168. http://dx.doi.org/10.2188/jea.JE20120087

[33] Watarai, R., Suzuki, K., Ichino, N., Osakabe, K., Sugimoto, K., Yamada, H., Hamajima, T., Hamajima, N. and Inoue, T. (2014) Association between Serum Levels of Carotenoids and Serum Asymmetric Dimethylarginine Levels in Japanese Subjects. Journal of Epidemiology, 24, 250-257. http://dx.doi.org/10.2188/jea.JE20130137

[34] Sugiura, M., Nakamura, M., Ogawa, K., Ikoma, Y. and Yano, M. (2015) High-Serum Carotenoids Associated with Lower Risk for Developing Type 2 Diabetes among Japanese Subjects: Mikkabi Cohort Study. BMJ Open Diabetes Research \& Care, 3, e000147. http://dx.doi.org/10.1136/bmjdrc-2015-000147

[35] Zhou, B.F., Stamler, J., Dennis, B., Moag-Stahlberg, A., Okuda, N., Robertson, C., Zhao, L., Chan, Q. and Elliott, P., INTERMAP Research Group (2003) Nutrient Intakes of Middle-Aged Men and Women in China, Japan, United Kingdom, and United States in the Late 1990s: The INTERMAP Study. Journal of Human Hypertension, 17, 623-630. http://dx.doi.org/10.1038/sj.jhh.1001605

[36] Davies, J.N. and Hobson, G.E. (1981) The Constituents of Tomato Fruit-The Influence of Environment, Nutrition, and Genotype. C R C Critical Reviews in Food Science and Nutrition, 15, 205-280. http://dx.doi.org/10.1080/10408398109527317

[37] Inoue, K., Shirai, T., Ochiai, H., Kasao, M., Hayakawa, K., Kimura, M. and Sansawa, H. (2003) Blood-Pressure-Lowering Effect of a Novel Fermented Milk Containing Gamma-Aminobutyric Acid (GABA) in Mild Hypertensives. European Journal of Clinical Nutrition, 57, 490-495. http://dx.doi.org/10.1038/sj.ejcn.1601555

[38] Shimada, M., Hasegawa, T., Nishimura, C., Kan, H., Kanno, T., Nakamura, T. and Matsubayashi, T. (2009) Anti- 
Hypertensive Effect of Gamma-Aminobutyric Acid (GABA)-Rich Chlorella on High-Normal Blood Pressure and Borderline Hypertension in Placebo-Controlled Double Blind Study. Clinical and Experimental Hypertension, 31, 342354. http://dx.doi.org/10.1080/10641960902977908

[39] Nishimura, M., Yoshida, S., Haramoto, M., Mizuno, H., Fukuda, T., Kagami-Katsuyama, H., Tanaka, A., Ohkawara, T., Sato, Y. and Nishihira, J. (2015) Effects of White Rice Containing Enriched Gamma-Aminobutyric Acid on Blood Pressure. Journal of Traditional and Complementary Medicine, 6, 66-71. http://dx.doi.org/10.1016/j.jtcme.2014.11.022

[40] Ahn, J., Lee, H., Jung, C.H. and Ha, T. (2012) Lycopene Inhibits Hepatic Steatosis via microRNA-21-Induced Downregulation of Fatty Acid-Binding Protein 7 in Mice Fed a High-Fat Diet. Molecular Nutrition \& Food Research, 56, 1665-1674. http://dx.doi.org/10.1002/mnfr.201200182

[41] Chung, J., Koo, K., Lian, F., Hu, K.Q., Ernst, H. and Wang, X.D. (2012) Apo-10'-Lycopenoic Acid, a Lycopene Metabolite, Increases Sirtuin 1 mRNA and Protein Levels and Decreases Hepatic Fat Accumulation in ob/ob Mice. The Journal of Nutrition, 142, 405-410. http://dx.doi.org/10.3945/jn.111.150052

[42] De Luvizotto, R.A., Nascimento, A.F., Imaizumi, E., Pierine, D.T., Conde, S.J., Correa, C.R., Yeum, K.J. and Ferreira, A.L. (2013) Lycopene Supplementation Modulates Plasma Concentrations and Epididymal Adipose Tissue mRNA of Leptin, Resistin and IL-6 in Diet-Induced Obese Rats. British Journal of Nutrition, 110, 1803-1809. http://dx.doi.org/10.1017/S0007114513001256

[43] Li, Y.F., Chang, Y.Y., Huang, H.C., Wu, Y.C., Yang, M.D. and Chao, P.M. (2015) Tomato Juice Supplementation in Young Women Reduces Inflammatory Adipokine Levels Independently of Body Fat Reduction. Nutrition, 31, 691-696. http://dx.doi.org/10.1016/j.nut.2014.11.008

[44] Kanamoto, I., Inoue, Y., Moriuchi, T., Yamada, Y., Imura, H. and Sato, S. (2010) Effect of Differences in Low Glycemic Index Food Intake Sequence on Plasma Glucose Profile. Journal of the Japan Diabetes Society, 53, 96-101. (In Japanese)

[45] Imai, S., Matsuda, M., Miyatani, S., Hasegawa, G., Fukui, M. and Kajiyama, S. (2010) Crossover Study of the Effect of "Vegetable Before Carbohydrate" on the Reduction of the Postprandial Glucose and Insulin Levels in Japanese Patients with Type 2 Diabetes Mellitus. Journal of the Japan Diabetes Society, 53, 112-115. (In Japanese)

[46] Kasuya, N., Okuyama, M., Yoshida, K., Sunabori, S., Suganuma, H., Murata, I., Inoue, Y. and Kanamoto, I. (2016) Prior or Concomitant Drinking of Vegetable Juice with a Meal Attenuates Postprandial Blood Glucose Elevation in Healthy Young Adults. Food and Nutrition Sciences, 7, 797-806. http://dx.doi.org/10.4236/fns.2016.79080

[47] Monnier, L., Colette, C., Dunseath, G.J. and Owens, D.R. (2007) The Loss of Postprandial Glycemic Control Precedes Stepwise Deterioration of Fasting with Worsening Diabetes. Diabetes Care, 30, 263-269. http://dx.doi.org/10.2337/dc06-1612

[48] Boushey, C.J., Beresford, S.A., Omenn, G.S. and Motulsky, A.G. (1995) A Quantitative Assessment of Plasma Homocysteine as a Risk Factor for Vascular Disease. Probable Benefits of Increasing Folic Acid Intakes. JAMA, 274, 1049-1057. http://dx.doi.org/10.1001/jama.1995.03530130055028

[49] Brouwer, I.A., van Dusseldorp, M., West, C.E., Meyboom, S., Thomas, C.M., Duran, M., van het Hof, K.H., Eskes, T.K., Hautvast, J.G. and Steegers-Theunissen, R.P. (1999) Dietary Folate from Vegetables and Citrus Fruit Decreases Plasma Homocysteine Concentrations in Humans in a Dietary Controlled Trial. The Journal of Nutrition, 129, 11351139.

[50] Riddell, L.J., Chisholm, A., Williams, S. and Mann, J.I. (2000) Dietary Strategies for Lowering Homocysteine Concentrations. The American Journal of Clinical Nutrition, 71, 1448-1454.

[51] García-Casal, M.N., Layrisse, M., Solano, L., Barón, M.A., Arguello, F., Llovera, D., Ramírez, J., Leets, I. and Tropper, E. (1998) Vitamin A and Beta-Carotene Can Improve Nonheme Iron Absorption from Rice, Wheat and Corn by Humans. The Journal of Nutrition, 128, 646-650.

[52] Maramag, C.C., Ribaya-Mercado, J.D., Rayco-Solon, P., Solon, J.A., Tengco, L.W., Blumberg, J.B. and Solon, F.S. (2010) Influence of Carotene-Rich Vegetable Meals on the Prevalence of Anaemia and Iron Deficiency in Filipino Schoolchildren. European Journal of Clinical Nutrition, 64, 468-474. http://dx.doi.org/10.1038/ejcn.2010.23 


\section{Submit or recommend next manuscript to SCIRP and we will provide best service for you:}

Accepting pre-submission inquiries through Email, Facebook, LinkedIn, Twitter, etc.

A wide selection of journals (inclusive of 9 subjects, more than 200 journals)

Providing 24-hour high-quality service

User-friendly online submission system

Fair and swift peer-review system

Efficient typesetting and proofreading procedure

Display of the result of downloads and visits, as well as the number of cited articles

Maximum dissemination of your research work

Submit your manuscript at: http://papersubmission.scirp.org/ 